University of Louisville

ThinkIR: The University of Louisville's Institutional Repository

Electronic Theses and Dissertations

$5-2013$

\title{
The palm of my hand : keeping an audience engaged as Benedick in Much ado about nothing.
}

Jake Beamer

University of Louisville

Follow this and additional works at: https://ir.library.louisville.edu/etd

\section{Recommended Citation}

Beamer, Jake, "The palm of my hand : keeping an audience engaged as Benedick in Much ado about nothing." (2013). Electronic Theses and Dissertations. Paper 88.

https://doi.org/10.18297/etd/88

This Master's Thesis is brought to you for free and open access by ThinkIR: The University of Louisville's Institutional Repository. It has been accepted for inclusion in Electronic Theses and Dissertations by an authorized administrator of ThinkIR: The University of Louisville's Institutional Repository. This title appears here courtesy of the author, who has retained all other copyrights. For more information, please contact thinkir@louisville.edu. 
THE PALM OF MY HAND:

KEEPING AN AUDIENCE ENGAGED AS

BENEDICK IN MUCH ADO ABOUT NOTHING

\author{
By \\ Jake Beamer \\ B.A., University of Kentucky, 2007
}

\begin{abstract}
A Thesis
Submitted to the Faculty of the

In Partial Fulfillment of the Requirements

For the Degree of

Master of Fine Arts

Department of Theatre Arts

University of Louisville

Louisville, Kentucky
\end{abstract}

College of Arts and Sciences of the University of Louisville

May 2013 
Copyright 2013 by Jake Beamer

All rights reserved. 

THE PALM OF MY HAND:

KEEPING AN AUDIENCE ENGAGED AS

BENEDICK IN MUCH ADO ABOUT NOTHING

By
Jake Beamer
B.A., University of Kentucky, 2007

A Thesis Approved on

April 19, 2013

by the following Thesis Committee:

Michael Hottois

Thesis Advisor

Nefertiti Burton

Dr. Jay Irby 


\section{ACKNOWLEDGMENTS}

I would like to thank the people who have influenced me to be bold, taught me the value of being professional, and inspired me more than they will ever know: Lauren "Lala" Argo, Lauren "Fancy" Carr, Mylissa Crutcher, Craig Branch, Kyle Weishaar, Jenny Fitzpatrick, Mac King, Dara Tiller, Nick Dunn, Alex Kluemper, Margo Buchanan, Nancy Jones, Andrew Kimbrough, Bill Kincaid, Amy Steiger, Russell Henderson, Nelson Fields, Bob Haven, John Holloway, Tony Hardin, Kathleen Smith, Debbie Dougherty, Dorothy Zbornak, Blanche Devereaux, Rose Nylund, and Sophia Petrillo.

I would also like to thank my thesis committee, Michael Hottois, Nefertiti Burton, and Dr. Jay Irby for their time and dedication, the faculty of the Theatre Arts Department, and Jim Tompkins for his direction and support.

I would also like to thank Cara McHugh, Jocelyn Matsuo, and Lauren Street. We did it! 


\section{ABSTRACT \\ THE PALM OF MY HAND: \\ KEEPING AN AUDIENCE ENGAGED AS BENEDICK IN MUCH ADO ABOUT NOTHING}

Jake Beamer

April 19, 2013

This thesis briefly describes the process by which I was able to portray Benedick in William Shakespeare's Much Ado About Nothing in November 2012; my own desire for approval from experienced artists; and the value of modernizing a Shakespearean text for the contemporary, University of Louisville audience. With the use of my own natural talent, the training I received from accredited institutions, and my work in the professional world, I was able to create a performance that was theatrically viable to my audience. I examine why I wanted to receive my Master's Degree of Fine Arts and conclude that performing as Benedick has allowed me to achieve those goals.

The thesis is comprised of five chapters including the search for approval, formal training and professional work, graduate training, Much Ado About Nothing, and conclusion. The first half of the thesis is focused on my personal and performance histories and their influences on training on the graduate level as well as the performance of Benedick. The latter half of the thesis is centered on how I created my performance. 
TABLE OF CONTENTS

PAGE

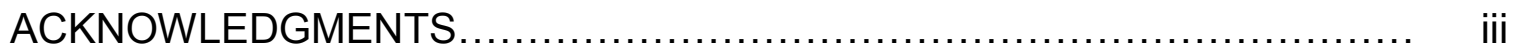

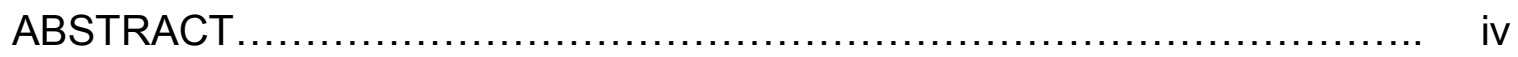

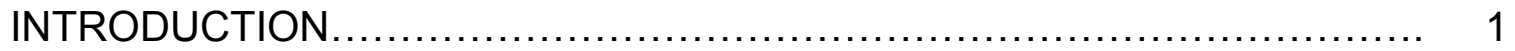

CHAPTER ONE: THE SEARCH FOR APPROVAL $\ldots \ldots \ldots \ldots \ldots \ldots \ldots \ldots \ldots . \quad 3$

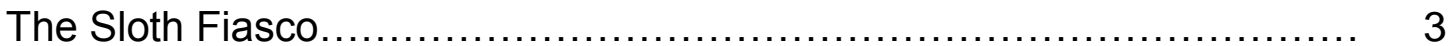

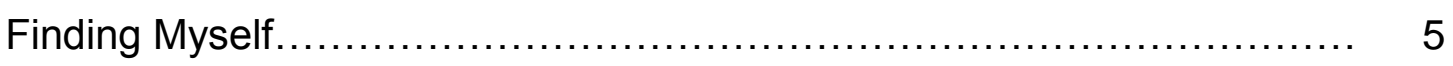

CHAPTER TWO: FORMAL TRAINING AND PROFESSIONAL WORK ....... 8

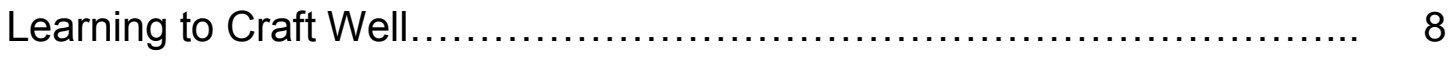

Honing my Craft....................................................... 13

Advanced Actor Training ................................................. 15

The West Coast............................................................. 16

CHAPTER THREE: GRADUATE TRAINING.............................. 20

Why I Wanted an MFA ............................................... 20

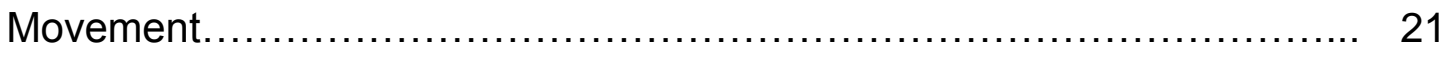

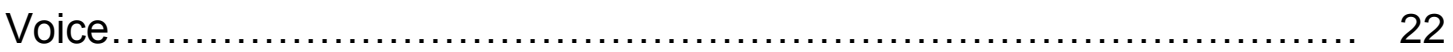

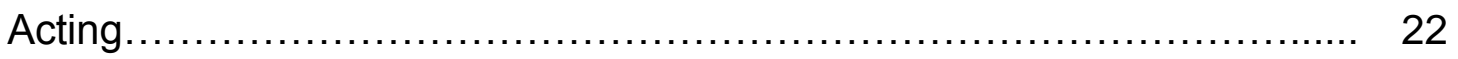

Academic Courses....................................................... 24

CHAPTER FOUR: MUCH ADO ABOUT NOTHING.......................... 25

Why Benedick? .......................................................................... 25 


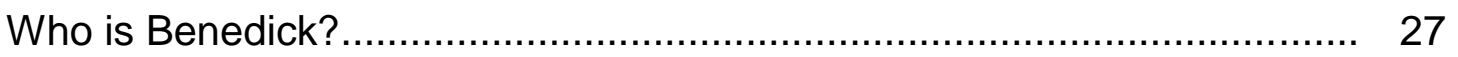

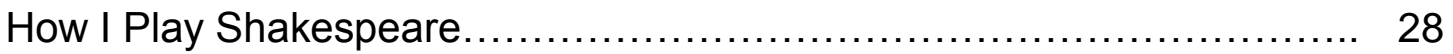

Keeping the Audience in the Palms of our Hands.......................... 31

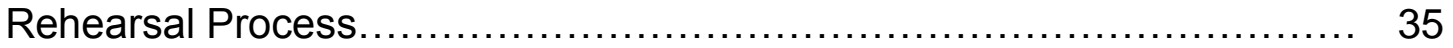

My Process During the Show........................................... 39

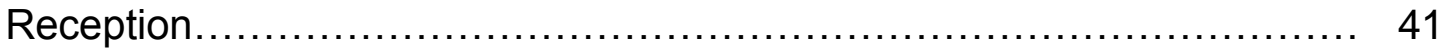

CHAPTER FIVE: CONCLUSION ......................................... 44

FIGURE ONE: LAOCOÖN AND HIS SONS ............................ 46

FIGURE TWO: THE UNION OF EARTH AND WATER ...................... 47

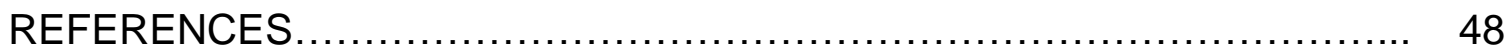

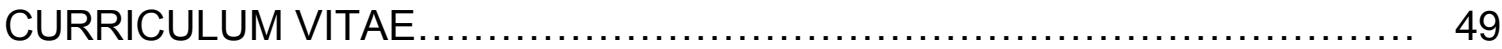




\section{INTRODUCTION}

"Acting is a very personal process. It has to do with expressing your own personality, and discovering the character you're playing through your own experience - so we're all different." - Sir lan McKellen

As far back as I can remember the need to seek approval has been very important to me and I have always wanted to be the center of attention. The art and craftsmanship of being an actor has allowed me to achieve these goals while nourishing my own creativity. Acting permits me to revel in manipulating an audience to experience those feelings that I want them to feel. A metaphor I often use to describe this action is that I can hold the audience in the palm of my hand and depending on how I open and close my fingers, I can make them feel joy, sadness, desperation, or elation. An audience, however, will not go willingly; they must be persuaded to allow me to influence them, and what I have garnered throughout my professional acting career and various training programs is the knowledge of how to do this successfully. My performance as Benedick in William Shakespeare's Much Ado About Nothing is the culmination of these learning experiences.

Much Ado About Nothing is a comedy first performed between 1598-1599 (Shakespeare 1387) about two sets of lovers, Benedick and Beatrice, Claudio 
and Hero, and plots of ruses and misprision ${ }^{1}$ to bind the couples in marriage. Benedick and Beatrice have a longstanding "merry war" between one another in which they declare their abhorrence for love, marriage, and perhaps most importantly, each other. In contrast, Claudio and Hero are the ingénues of this play and provide a textbook definition for love at first sight. Through gossip, deception, and eavesdropping on the townspeople of Messina, Benedick and Beatrice confess their love for each other, heal old wounds with their cohorts, and end the play with the impending marriages of both couples. The play is inundated with malapropism, misunderstanding, and verbal sparring and it is therefore very important that the audience understand the text being spoken.

Shakespeare is meant to be heard, not read, and the actors of any production must be able to convey the emotion, truth, and belief needed in order to keep the attention of an audience. Unfortunately, due the oftentimes archaic language of the Elizabethan period, Shakespeare's use of blank verse (iambic pentameter), and the heightened language of his prose, an audience can quickly lose its ability to hear the text. I believe, through training and a modernization of the original text, I was able to overcome the language barrier that afflicts so many mediocre performances of Shakespeare's masterpieces.

\footnotetext{
${ }^{1}$ Misprision in this usage means misunderstanding, not (a) neglect or wrong performance of official duty or (b) concealment of treason of felony by one who is not a participant in the treason or felony ("misprision").
} 


\section{CHAPTER ONE: THE SEARCH FOR APPROVAL}

\section{THE SLOTH FIASCO}

My acting career began in 1991 in my second year of school at the age of six. I had been cast as a sloth in a children's performance about the Amazon rainforest at my elementary school. I can remember being very excited about playing a sloth and I worked diligently to memorize the few lines that I had as well as the minimal choreography to the songs that we sang so that I could impress my family, friends, and perhaps most importantly, myself. This, unfortunately, would not be the case. My spotlight was turned off, my moment destroyed by my teacher. In a last-minute decision, for reasons still unbeknownst to me, I was relegated to the part of a tree whose sole purpose was to provide scenic background and backup vocals. Worst of all, I thought it was my fault. I thought because of something I did I was reduced to the shadows of the rainforest. The feeling of devastation that I was not going to perform as a main character for my family and friends was my catalyst for always striving for approval, the best roles, and my desire to be a star.

During my childhood I attempted other forms of artistic expression as a way to rectify the sloth fiasco. I joined the school band, learned to play saxophone, and participated in a talent show, but it never provided me with the satisfaction I craved. The band and talent show were group performances and I 
never felt like I was a standout performer amongst the crowd. That changed in 1996 when I entered sixth grade and joined Stuart Middle School's chorus. I did not have any interest in singing; I only took the class as a way to exempt myself from having to take Physical Education, as most of my peers were doing. To my surprise, I learned I had an impressive singing voice and would continue to be given solo performances throughout my three-year middle school career. For the first time since 1991, I was being recognized for my artistic abilities and the passion to do more was building inside of me.

In 1997, at the age of 12 , I was cast as the Scarecrow in Stuart Middle School's production of The Wiz. This was my opportunity to set right the humiliation that occurred six years earlier and I seized it. I worked harder than ever to try to give the best performance possible in order to atone for what I previously thought was my fault. It was my first chance to experience both the positive and negative situations that occur during live theatre as well as their respective emotions: feeling empowered by nailing a scene or song, adoration from a standing ovation, guilt for flubbing a line, anxiety about the possibility of failure, etc. After closing the show, I felt I had finally amended the sloth fiasco and could officially place this moment in my past; never forgetting, but certainly forgiving myself for what I thought were my own doubts. My performance in The Wiz fulfilled the need for approval that I so desperately craved; however, this need would resurface as I began to grow into adulthood. 


\section{FINDING MYSELF}

As I entered the pressured environment of high school, the approval I desired would come not as much from my family as my peers. I allowed their opinions to sway my decisions about my creative interests, my hobbies, even the students with whom I associated. Because of this I chose not to engage in the high school chorus or theatre classes, but instead to become a member of the newspaper where I would eventually become editor in chief. This position of authority was transference of the gratification I received while working theatrically. Had I not been chosen to be a Governor's Scholar in 2002, my career path may have been drastically different from whence it is now.

I spent five weeks on the campus of Eastern Kentucky University, experiencing residential life with a robust and diverse composition of students and teachers, in a liberal arts program of two artistic courses, Film and Art. During my tenure, I met people very unlike my peers in high school, people who were less bigoted, less exclusive, and with broader minds. I had always known something was different about me and for years, I actively chose to deny it, but from the melting pot of people and ideas that was the Governor's Scholars Program, I could finally admit to myself that I was gay. It would take longer to be able to admit to others my realization, but it was the first step on the road to acceptance of myself.

Upon returning to school as a senior, I slowly began to reveal the nature of my sexuality to my peers, which led to new friendships, which in turn led me to 
audition for Butler Traditional High School's performance of Up the Down Staircase by Bel Kaufman. Set in an inner-city high school, I was cast as J.J. McHabe, a stern administrative assistant in charge of discipline. McHabe was constantly battling the rough-around-the-edges and cheeky student, Joe Ferone, who happened to be played by a fellow gay student and my first gay crush that blossomed into a relationship. It was short-lived, however, and one evening before a show, Nathan told me, "I think you like me a lot more than I like you." Needless to say, I was devastated.

I remember sitting outside of the gymnasium crying my eyes out as the sun set on an orange horizon. During a moment between sobs I recognized the opportunity of my situation: I could use the emotions I was feeling right then and channel them on the stage, emotions that were real, raw, and true. It was not just a recognition, it was a requirement; I had to feed off that emotion otherwise I would not have been able to step foot on the stage. Without knowing the terminology or having ever studied the acting techniques of emotional recall, it was a logical solution to my current situation. That night I gave my best performance yet, and the subsequent nights I continued to use my true emotions to fuel the intentions of my character. I was so angry with Nathan that it was effortless to transfer that hatred to his character of Joe, the antagonist of my own character. If J.J. McHabe yelled at Joe, the yell was sustained with the pain that Nathan had caused me. If J.J. treated Joe badly or with disdain it was enhanced by my own feelings of contempt. This in turn would influence my interactions with those characters that had different sentiments of Joe; I would immediately 
disregard them as lower status. Years later it would be this event which fortified my opinions on the nature of acting, what defined good acting, and how it shaped my own process.

As my senior year drew to a close I debated entering either the University of Kentucky's journalism or theatre programs - I chose the latter. Until then, I never really thought of acting as a career, but my own personal success with Up the Down Staircase led me to want nothing else. 


\section{CHAPTER TWO: UNDERGRADUATE TRAINING \& PROFESSIONAL WORK}

\section{LEARNING TO CRAFT WELL}

I received my undergraduate training from the University of Kentucky's Theatre Department from 2003 - 2007. The Bachelor's of Arts curriculum consisted of a well-rounded program of studies in all facets of theatre; I studied theatre history, acting, directing, playwriting, movement, dance, costume construction, stage craft, lighting and sound technology, scenic design, lighting design, stage speech, dialects, African American theatre (specifically, the works of August Wilson), and classical acting styles (specifically Shakespeare, French Neo-Classical, and Restoration). Looking back, I am glad to have received the benefit of learning such a plethora of theatrical knowledge which led to my first professional job after graduation.

I excelled in all of my classes but my affinity lay with the acting courses. My first semester, I studied under Margot Buchanan, an Equity actress living and working in Lexington, Kentucky. She quickly became a mentor due to her passion for the craft and her ability to teach; it was her direction that led me to believe that although it can be a natural talent, acting is also a learned skill. The first day of class, she simply told us, "Acting is believing. If you are supposed to be sad in a scene, then cry," and she proceeded to do so. "If you are supposed to be angry and leave the room then get angry and leave the fucking room!" she 
screamed, and proceeded to throw her teaching materials to the floor and storm out slamming the door behind her to a class of stunned students, myself included. Her conviction and use of emotion made a lasting impression on me; I repeat those words of wisdom to the acting classes that I teach. Her performance cemented what I had discovered in high school: acting with real emotions from your past is the best method for conveying truth on stage. It was an important, albeit brief, lesson that truly good acting is real, not just a recreation of emotions and attitudes. My performance as Benedick was informed by this. His anger at Claudio is real, with a flicker of Nathan's pain hiding just below the surface. Margot would continue to teach me, through classroom instruction and play direction, the finer points of good performance until her contract with the university ended.

My first show at the University was a Christmas play titled, The Workshop, a comedic endeavor written by then-student Templeton Moss about the goingson of Santa's technologically and ideologically outdated workshop in an increasingly modern world. The piece was intended to be just a Studio Show not to be produced for UK's mainstage season; however, the script's interest by certain faculty garnered the production departmental funds and resident faculty positions of director, lighting, and scenic designs. I was swiftly thrown into the role of Santa Claus in what would become the best show of the season, despite not being performed on the mainstage. 
My portrayal of Santa, under the guide of Margo Buchanan as director, was rather typical except for his penchant for antique methods ${ }^{2}$, Bill Cosby sweaters, and chicken salad. It was during this production that I learned the value of time, responsibility, and trust as an actor in the theatre. During our final dress rehearsal, I missed a cue for my entrance because I was reattaching my white beard and moustache in the dressing room which was below the stage. By the time the assistant stage manager found me and yelled, "Jake, you're on!" I was almost three full-minutes late. I was fortunate that my cue was "Where the heck is Santa Claus?" so the rest of the cast was able to improvise looking for me to humorous effect, however during the note session after the show, Margo asked me to apologize to the cast for wasting everyone's time. She knew that it was not the most egregious error but it needed to be addressed. It was a lesson in professionalism that was a shaming, humbling, and beneficial experience that I never forgot, and to this day, if I or anyone else wastes the time of a cast or crew, I expect an apology.

The following semester I was cast in Steve Martin's Picasso at the Lapin Agile, as Sagot, Pablo Picasso's clever and witty art dealer. This was my first mainstage production at the University of Kentucky and I was fortunate once again to have Margot direct me in the role. Until that point my weaknesses included poor construction of a through-line in monologues, speaking too quickly, and mouthing the dialogue of fellow actors on stage. These novice shortcomings were revealed to me in private rehearsals with Margot and through practice, I

${ }^{2}$ Santa preferred to write his list by hand as opposed to using electronic devices. 
was able to overcome them. Luckily these mistakes were corrected early in my career and I repeat Margot's lessons to my own students (and classmates when applicable and appropriate) on how not to fall into the same trap. Should they speak too fast, I force them to slow their voice to a seemingly uncomfortable tempo reminding them that it sounds natural to an audience; if they are having trouble finding the ebb and flow of a long speech, I force them to break the speech up into Stanislavski's bits to find its spine; if I catch them on stage mouthing the words of their fellow actors, I immediately call them on it so they can later catch themselves doing it (Stanislavski 111-116). Shame is a powerful tool and it must be used delicately. I believe it is only appropriate if it can be used to teach valuable lessons like it did when I missed my entrance as Santa Claus. Professionalism, like good acting, can be learned, and my first professional acting job would come from summer stock, which is any theatre performed only in the summer months.

In the summer after my freshman year at the University of Kentucky, I was offered a role in Johnny Appleseed: The Outdoor Drama without having to audition. I was in a special position because the director of the production was my voice and dialect teacher, Russell Henderson. At the time, Johnny Appleseed was the highest paying, non-Equity, outdoor drama in the country. Not only was it a perfect first-experience as a new theatre artist, it was also an offer that I could not refuse. The production was an historical and musical drama about the life and times of John Chapman, better known as Johnny Appleseed. The characters were all based on real people who lived in Ohio during the early 
$19^{\text {th }}$ century. This was my first time portraying a once-living person on stage and subsequently my first time using dramaturgical research to create my character. I received the role of Ebenezer Rice whose daughter, Betsy Rice, would become the female ingénue of the production. Ebenezer was of little to no consequence in terms of actual plot, however I was also expected to play other roles and partake in the stage combat of the performance. There were many staged fight scenes including what we called "war," where nearly every company member was on stage fighting. I learned stage combat from a teacher certified by the Society of American Fight Directors, and after approximately 30 hours of study for each weapon, had my skills tested by Fight Director Brian Byrnes. I received recognition from the SAFD for proficient skills in unarmed, rapier and dagger, and quarterstaff combat. The accomplishments were an invaluable resource that I am still using in my career, and I have choreographed fight scenes for regional theatres in Kentucky, Ohio, and California, as well as the University of Kentucky and the University of Louisville.

I joined many of the cast and crew of Appleseed in what we termed "Second Season" productions. These were plays performed at a different venue than the Appleseed stage for the purpose of allowing the cast to perform in contemporary, comedic, and tragic shows unlike the often hokey Johnny Appleseed. While observing my peers perform, something clicked within me as if someone had turned on a light. I was suddenly able to see, hear, and understand what separated good theatre from bad. I had not perfected the art of 
its execution but I was now aware of how to spot it. I would return in the fall to the University of Kentucky with this knowledge.

\section{HONING MY CRAFT}

With a professional credit under my belt, my training with Margot would continue through my second and third acting courses where we experimented with the methodologies of Stanislavski, Meisner, and Adler applying them to Elizabethan theatre and Absurdism. My love of Shakespeare blossomed in this particular class as I learned the structure, complexity, intensity, and beauty with which the Bard wrote. In one exercise in scene work, I played the titular character from Richard III speaking to Queen Elizabeth about the future of the crown in regards to her daughter, also called Elizabeth. Richard's expert use of nuance, subtlety, cunning, and tact, while still revealing himself as a true villain, is so deft he became my dream role, one I have yet to play in a full production.

I would return to Appleseed the following summer at the request of Bill Kincaid. Bill had become a mentor and friend in 2004 where he served as music director. At the time, he was Professor of Theatre at Western Illinois University ${ }^{3}$, and he helped polish my singing voice through training and exercise, something that I was not receiving at the University of Kentucky as it was not a musical theatre program. His expertise would grant me the confidence in my own voice to sing in auditions and procure gigs that required musical prowess.

\footnotetext{
${ }^{3}$ Bill is currently Head of Acting at Western Illinois University.
} 
I was offered the roles of Martin Ruffner, another historical figure from John Chapman's life, and a non-speaking role as a Native American. The role of Ruffner was significantly larger than that of the previous season and included a large fight scene that would culminate in the climax of the show. It was the longest staged brawl in which I had ever participated and my skills as a fighter provided me with the stamina, energy, and focus to perform it six nights a week for three months.

My experiences as a professional theatre artist taught me the value of working as a company, an ensemble, perhaps most importantly, an individual. During my time with Johnny Appleseed I met those other actors that would create a significant impact on my work; I learned how to delineate truly good acting from the bad and apply what construed the good to my performances, as well as the performances of those people I would direct. Returning to the University of Kentucky in the fall of 2005, I took my first Directing course, and without the aspects I learned from my directors, coworkers, and friends, my craft would have suffered.

In the summer of 2006 , I got a job as a server at a Lexington seafood restaurant as well as auditioned for the Lexington Shakespeare Festival's production of Much Ado About Nothing, directed by Joe Ferrell. I was cast as Don John, the surly antagonist and brother to Don Pedro, because of my command and skill of the Shakespearean language gleaned from my studies at UK. 


\section{ADVANCED ACTING TRAINING}

My classical acting styles would further progress under the tutelage of Dr. Andrew Kimbrough, a professor who would become my friend and primary mentor. Andrew was the first professor to teach me about what I like to call a larger-than-life-realness that is required of all classical texts, especially those of a Shakespearean nature. He taught us the epic, lyric, and dramatic forms of speech when acting the classics which would influence my process throughout my career. His instruction culminated in my final production at the University of Kentucky as Saturninus in Titus Andronicus and my undergraduate thesis which was the creation of a Shakespearean acting workshop to teach my cast mates how to properly speak the words of Titus with true feeling, not just a rote recitation of the text. I titled the workshop "Shake-Shop" and it was highly effective in producing a quality Shakespearean performance from the cast; a cast that was relatively new to the language, blank verse, emotional content, and intricacy of Titus; a cast that did not receive instruction from a director knowledgeable of the classical acting style. The training I received from Dr. Andrew Kimbrough would energize my process of acting for the bulk of my professional career; to include not only classic works but also period and modern theatrical pieces.

Following my graduation in May of 2007, I auditioned for Blue Jacket, another Outdoor Drama located in Ohio, this time in the city of Xenia. I was offered the role of Lt. Antoine DeQuindre, a French-Canadian military officer who joined with the Shawnee in the siege of Fort Boonesborough. My experience at 
Blue Jacket was quite unlike my time at Appleseed. The play was not a musical. It contained more violence and was subsequently far less family-friendly. Horses played a prominent feature and most actors, myself included, rode them in the show and were responsible for attending to them after. I used a French dialect for my work as DeQuindre, learned and used authentic Shawnee sign language on stage, and our director, Mark Guinn, was an SAFD Certified Teacher who let us choreograph our own fight scenes. Ultimately, this was the best and most useful Outdoor Drama experience in my career.

Furthermore, I was offered the chance to advance my weaponry skill set in stage combat: I learned knife, broadsword, and sword and shield, thus having taken and passed the Skills Proficiency Test in a total of six weapons. The decision to earn more recognition from the SAFD would lead to my success in achieving callbacks at large auditions such as the South Eastern Theatre Conference and the Unified Professional Theatre Auditions. One such callback at SETC would lead to my employment as a company member of the California Theatre Center.

\section{THE WEST COAST}

The California Theatre Center is a non-profit children's theatre based in Sunnyvale, California. I left Louisville for The Golden State and traveled three days by car to Sunnyvale, venturing west of the Mississippi River for the first time in my life. The position with CTC was described by its Administrative Director as, "a place for new graduates to hang their hat for a couple of years," and that is 
exactly what I did. For two years I worked as a company member with duties that required full use of my training in all aspects of theatre, an education I received while at the University of Kentucky. Acting with the company was my primary role, however, because of my expertise I was often asked to choreograph fight sequences, design lights and sound, work as a crewmember in the scene and costume shops, stage manage, and direct.

Some shows would tour in one of two settings, if not both: local tours were day trips where the cast would drive to a venue, perform a show, and return to Sunnyvale in the same day; and long tours, which consisted of traveling to venues in California, Oregon and Nevada, and performing for weeks at a time. I toured a majority of the West Coast, from as far north as Bellingham, WA, and south to Los Angeles. It was a life changing experience to see so much of the country that I had never visited, something my immediate family has never done. The opportunities to apply my experiences as a touring artist to the betterment of becoming a professional actor were boundless: sharing wisdom and worldliness with locals; creating friendships and networking with others in the theatrical business; performing daily, honing my craft into a repeatable, yet novel and exciting exercise; bringing theatre to many youth for the first time; learning to live and work with my cohorts; etc.

During summer months, my job focused on two facets: being a Teaching Artist for our Summer Conservatories, two month-long camps, one for children age 7-13, one for high school students age 14-18; and acting in Repertory for our Adult and Family Series of plays produced at the Sunnyvale Community Center. 
At Conservatory, CTC employees taught the participants techniques in acting, movement, and voice, as well as instructing them on making their own sets, props, and costumes in a production that we would direct. I was primarily Production Manager/Lead Teacher for the Conservatories, which had added responsibilities of disciplining the students, discussing matters with their parents, reporting to administration, and making final decisions in regards to the show that the children were creating. The goal of Conservatory was to allow the students to showcase their talents for their family and friends in a production they created. This goal was heightened for the older students as many of them were learning to be performers in high school with hopes of attending a collegiate theatre program. The awareness that I was passing knowledge on to the future of theatre artists was a stimulus for my decision to return to school to attain my Master's Degree; I believed teaching was in my future.

In 2009 I did not renew my contract with the California Theatre Center, mainly due to administrative policies that conflicted with my personal values, but also because I was ready for consistent, more challenging work. Little to no direction from the artistic staff ${ }^{4}$ had forced me to perform as I saw fit and I became a poor judge of my own work. I had become indifferent to my performances after two years of relying on an audience of children and young people to provide me with approval and validation. I had achieved the approval but now I needed it from an older, theatrically wiser audience. Burned out on theatrical work, I returned to Kentucky where I witnessed a show at the Humana

\footnotetext{
${ }^{4}$ Mr. Will Huddleston, actor, playwright, and resident director for CTC is an exception to this. He is wonderful.
} 
Festival in 2010. I was so moved by it that I gave it a standing ovation, something I rarely do because such an expression should be reserved only for those moments when a production ends and you are literally moved to your feet to applaud. The Method Gun (The Rude Mechanicals 2010) did that for me and I wanted to share in that feeling; I wanted to be the one whose talent was so great that the audience was moved to their feet, not because I could do a simple song and dance in a children's show. This performance was an example of the more challenging work for which I had been looking and ultimately became the deciding factor for choosing to attend graduate school. 


\section{CHAPTER THREE: GRADUATE TRAINING}

\section{WHY I WANTED AN MFA}

The Method Gun "explores the life and techniques of Stella Burden, actortraining guru of the 60 s and 70 s using found text from the journals and performance reports of Burden's company." This play recounts the creation of the her company, which I found to be a zany, yet charming depiction of the combined talent, skill, and continued training that is required of actors to be successful in their careers. Upon reading the program for the show I realized most of the actors were not much older than me, and yet all of them had their Master's Degree of Fine Arts. I was so enthralled by what I had seen that night at the Humana Festival I thought it was only appropriate to also earn my MFA. I auditioned at the University of Louisville and received my acceptance letter in the summer of 2010 . At my audition I was asked by the faculty why I wanted to continue my training. My answer was three fold: to restore my passion for the art form I had lost during my stint with theatre for young audiences; to learn to trust my instincts again; and to graduate with the ability to teach college-level courses. I was to achieve this through a curriculum of six semesters of acting classes, four semesters of voice classes, four semesters of movement classes, and 15 hours of academic theatre courses. 


\section{MOVEMENT}

Professor Jim Tompkins taught movement with a focus on the Lecoq technique of mime and neutral mask work. Movement had always been an interesting if not testing experience because he forced us to figure out the technique on our own. It was quite commonplace that he would require us to perform without fully describing what was expected. For example, during the first year of study we received exercises titled "Circles and Curves", "45, 90, 180", or "War" and were expected to create group movement pieces without any instruction. Typically, it was futile and, in ordinary Tompkins-style, we would be told why it was wrong so it could be adjusted and corrected. However frustrating this process would become, in the end it was important; it was the epitome of the theatre mantra, "Try. Fail. Try Again. Fail Better," and by the end of that year it paid off. Our final exam was to choose a piece of modern art from the J.B.

Speed Museum and turn it into a movement piece, which we did with gusto and to rave reviews from Tompkins. So rave, in fact, that when he told the museum staff about them they asked us to perform them in front of the artworks. What was a private final became a public performance and based on Tompkins' level of expectations it was obviously a good one. His teaching style would ultimately help me trust my own instincts again, something I was afraid I had lost because of the lack of direction from working in children's theatre. 


\section{VOICE}

Dr. Rinda Frye exclusively taught voice class with the first semester centered on learning the Linklater technique of freeing the natural voice in conjunction with stage performance. Unfortunately, this was the only voice technique we covered in depth and my use of it was reserved for class work and rehearsal for those productions directed by Dr. Frye. The second semester involved further use of the Linklater progression as well as beginning to learn the International Phonetic Alphabet, which would prepare us for our second year in which we continued to refine our use of the IPA to transcribe dialects for performance. Learning the IPA was certainly helpful, but the repetitive nature of translating a speech into a dialect, being coached by Dr. Frye or other students, and being graded solely on one performance made it a laborious process. The most beneficial aspect of voice class was learning the IPA so I can have a formula for learning new dialects, including my Eastern Kentucky dialect that I used for Much Ado About Nothing. My group final, a parody of the game show "The Match Game" used nine different dialects and a combination of scripted and improvised dialogue, was well received by Dr. Frye and Professor Tompkins, which validated my work. Creating my own theatre, as opposed to relying on a playwright's text, was rekindling my passion for theatre.

\section{ACTING}

Acting courses had the most diverse group of instructors: five in six semesters. They were Professor Tompkins, Dr. Frye, Mrs. Zan Sawyer-Dailey, 
Mr. Daniel Hill, and Ms. Erin Crites. Tompkins' do-it-yourself teaching style continued to sharpen my ability to discover in myself what was good and bad. Just like his movement classes, Tompkins expected economy and I learned the value of what he called "real talk" and upward-ending voice inflections. The concept of inflections and their correlation to energizing a text pervades my theatrical process and listening for it is now my chief tool in evaluating theatrical performances.

Mrs. Zan Sawyer-Dailey is the Associate Director for Actors Theatre of Louisville and taught my acting classes for two semesters. Her specializations were audition techniques, business protocol, and scene studies. Often my criticisms from the faculty were that I needed to work on my emotional range and allow myself to be more vulnerable and it was only during Zan's classes that I was able to work with contemporary monologues and scenes to improve my inadequacies. It also allowed me to use the methods of analyzing a script that I learned from my academic courses.

Dr. Frye's acting class focused on her own technique for playing Shakespeare and although I found her information useful, a majority of the instruction I had already learned from my undergraduate training, her rehearsals of Measure for Measure and Richard III, and John Barton's Playing Shakespeare. Learned information were First Folio spellings being clues to speak the lines and the theory that breathing at the ends of verse lines more accurately evokes the emotion Shakespeare had intended. Richard III was a primary source for our scene work, which was terribly frustrating for me. Richard 
is my dream role and I had the misfortune of watching another graduate student butcher it in class as well Dr. Frye's production of Richard III. Cast as Henry, Earl of Richmond and Richard's nemesis, I was able to channel my distaste for the actor onto the stage, much as I did in high school. During our only interaction onstage, a duel to the death with rapiers and daggers, my real anger fueled the emotions that I allowed my character to feel. It was quite cathartic.

\section{ACADEMIC COURSES}

Academic courses consisted of "Playscript Analysis," taught by Dr. Russell Vandenbroucke; "Performance Theory" and "Tools for a Global Theatre," instructed by Dr. Amy Steiger; and "Approaching African American Theatre," by Dr. Lundeana Thomas. The courses taught by Drs. Vandenbroucke and Steiger provided the knowledge most applicable to a theatre artist. I learned the ideologies and performance techniques/analyses that would lead me to question: What is or is not theatre? Can theatre be defined? If so, what constitutes good theatre? Can it be quantified? Can my own opinion be supported with analytical information? The answers to those questions would form the basis of my acting process to produce quality theatre, and perhaps more importantly, to have a successful thesis experience. 


\section{CHAPTER FOUR: MUCH ADO ABOUT NOTHING}

\section{WHY BENEDICK?}

"The comedy of this Benedick and Beatrice plot is not the simple, sentimental indulgence of the "boy meets girl" pattern, although that is included; rather it lies in the entertaining, good-natured, critically aware contemplation of the dents in human nature shown in (a) their antagonism (there incapacity to leave one another alone); (b) there deception by contrived intrigue; (c) the revelations which spring from this, under the pressure of circumstances (that arise from the main plot): leading to (d) reversal of all their first positions (Rossiter 51)".

Performing Shakespeare and other classic works is my forte; I excelled in my Classical Acting courses in undergrad and taught others how to play Shakespeare for my undergraduate thesis, so why pick Much Ado About Nothing as my graduate thesis? I didn't. There is a myth that a graduate student in the Theatre Arts Department has a say in choosing a thesis role; that is both true and untrue. True in that, as a third-year student you are allowed to propose plays that would be suitable for thesis roles. Untrue in that the decision is ultimately made by the Season Selection Committee, which chooses plays that are in the best interest of the department. A multitude of factors is considered during the selection process: the number of thesis roles available; the size of the cast and available talent; the performance's budget; and a play's suitability for academia. The director of the production is also a factor. He or she will often already have a particular show in mind. I was told in my first year rarely do students perform in their proposed thesis plays due to the above concerns. I became aware of the 
futility in fighting for a show I wanted after seeing the choices that were made for the third-year students during my first and second years. Because of this fact, I decided to have only one request for my thesis: that Professor Tompkins direct me. During my tenure at the University, I had never been directed by him and the other Shakespearean roles I had received were Angelo, from Measure for Measure, and Henry, Earl of Richmond, from Richard III, both directed by Dr. Frye. Although I admit her knowledge of Shakespeare's works is extensive, when choosing the director for my piece I thought it would be unwise to have only one perspective on such classics. I wanted to leave the program with the benefit of having been directed by both of the Acting faculty members as well as more than one method to playing Shakespeare. In the end, my thesis, Benedick, was chosen for me but I was grateful to be directed by Tompkins.

I would have preferred to perform a contemporary piece considering I was not offered the chance to do so on the mainstage during my residency, but it was not my decision to make. I wanted a thesis role that would showcase my ability to draw down from the large stage presence and overdramatizing of which I was criticized by the faculty. I often find myself playing larger-than-life because the epic roles of classical theatre, as well as the Esu character from How Orisanmi Chose His Head ${ }^{5}$, offered to me at the university, in my opinion, should be played as such. Their goals are usually far more difficult to attain and the penance for failing are often worse than in the real world. Combining realistic acting styles with the epic, lyric, and dramatic forms that classic works require is certainly an

\footnotetext{
${ }^{5}$ How Orisanmi Chose His Head is a play written and directed by Nefertiti Burton about the Yoruba spiritual system. Esu is one of the most well known deities in Yorubaland.
} 
exercise in sharpening acting technique, but I do not feel it can be used to convey effectively the emotion, tension, and drama that works containing such ambitious material require. This became somewhat of a habit however, and during in-class scene work, my large stage presence would overshadow subtle nuances and other performers. I actively fought against this, and though it was not my choice, I was determined to win the faculty's approval with my portrayal of Benedick.

\section{WHO IS BENEDICK?}

I have been acting for ten years now, and I like to think that I am pretty good at it. What I mean is I easily understand concepts within scripts and can often hear how they should be said in my head, which allows me to replicate that as I speak it. Cohen's book, Acting One (1984), in conjunction with Professor Tompkins' acting course, helped me finesse this talent. Tompkins made it clear that Shakespeare's plays were not driven by plot, but it was the characters that carried the story into the hearts and minds of his audiences. "The interest in the plot is always in fact on account of the characters, not vice versa, as in almost all other writers; the plot is a mere canvas and no more (Rossiter 55)." Benedick has a vigorous, if not boorish, personality and it was my goal to highlight both his high energy and his compassion. This was a challenge considering

Shakespeare wrote the character as such a detractor of love:

That a woman conceived me, I thank her; that she brought me up, I likewise give her most humble thanks...Because I will not do them the wrong to mistrust any, I will do myself the right to trust none; and the fine is, for the which I may go the finer, I will live a bachelor. $(I, i, 162)$ 
Benedick states should he ever fall in love it would be with a woman who has all the virtues, is rich, and would never cheat on her husband (which is a woman he flatly believes does not exist). This account perhaps makes Benedick an unlikeable character, but other characters describe him differently: the Messenger introduces him as a "good soldier", "stuffed with all honorable virtues"; the Prince, Don Pedro, and Leonato paint him "valiant" and "honest". When approaching a character I find it vital to refer to other character's depictions of him, and these textual clues lead me to believe that Benedick's distaste for love is fueled by a passion tender enough to make him write a love poem to Beatrice, agree to kill Claudio to right Hero's good name, and profess his love for Beatrice in front of the whole town:

In brief, since I do purpose to marry, I will think nothing to any purpose that the world can say against it; and therefore never flout at me for what I have said against it; for man is a giddy thing, and this is my conclusion. ( $\mathrm{V}$, iv, 99)

In order to effectively convey both sides of Benedick's coin I had to employ a number of techniques I learned from the University of Kentucky, the University of Louisville, John Barton's Playing Shakespeare, and real-world experience.

\section{HOW I PLAY SHAKESPEARE}

If we don't reach our audience we fail. We must make them listen and share and follow the story. But above all, listen. It's so easy for an audience not to listen, particularly with a knotty and difficult text. I may be cynical but I don't believe most people really listen to Shakespeare in the theatre unless the actors make them do so. I certainly don't. I know that it's too easy for me to get the general gist and feeling of a speech, but just because I get the gist I often don't listen to the lines in detail. Not unless the actors make me

(Barton 7). 
I agree wholeheartedly with what John Barton says and therefore made it my job to make my audience listen. I believe this includes not only the paying customers but also my fellow actors on stage; they must be able to listen truly to what is being said in order to absorb it and react according to how it makes them feel. Sir lan McKellen states, "It's not enough to be aware of our own thoughts, feelings, our own words. We must listen to the words and understand the feelings and the thoughts of the other characters (Barton 9)". This is the biggest tenet of my process as an actor, to live in the moment and react with purposefulness to what is being said or done onstage. "Purposefulness is what ties the liberated voice to the actor's approach...Actors should speak onstage the way people normally do in life, not because they have to but because they want to (Cohen 134)". Every word spoken as Benedick had to be directed toward my goal to keep the audience in the palm of my hand. To sustain this throughout the entire play required a fantastic amount of energy. The audience will not follow you if you do not provide them an opportunity to ride the wave of your drive, your energy. In a piece such as Much Ado with its rises and falls of comedy, this can be especially difficult to accomplish during those moments of tragedy. For example, when speaking to Beatrice about her wronged cousin, I had to play up the rising comedic tension of professing my love for her, then immediately switch tactics when she bids me to kill Claudio. I purposely raised my voice and yelled at Beatrice to compel her to prove to me that she believed Claudio should die for his crime. The first instance of this happening occurred during a rehearsal and Jocelyn Matsuo's ${ }^{6}$ response as Beatrice to my bellow was enough to convince

${ }^{6}$ Jocelyn Matsuo, fellow third-year. Beatrice was her thesis role. 
me, and subsequently Benedick, that in order to gain Beatrice I had to lose Claudio. This reaction was then translated to the audience.

Drives such as this are also important for not allowing a character to wallow in self-pity. I am a firm believer that pity should not be given to a character for the sake of pity alone. During Benedick's monologue about how Beatrice misused him during the masquerade scene ${ }^{7}$, Professor Tompkins and I did not want the audience, Don Pedro, Leonato, or Hero to sympathize with me because I was whining about being hurt, quite the opposite. I wanted to convey to them that Beatrice was, in fact, the wretched creature and therefore hurled insult upon insult behind her back. The comedy comes not from pity but from Benedick's deflation at having his pride hurt by Beatrice, and his retaliation is defaming her character. The humor peaks when Beatrice enters, unbeknownst to me, and instead of apologizing or back peddling, Benedick simply asks Don Pedro for an errand to leave Beatrice's presence. The humiliation he feels for being caught in the act of saying terrible things about a woman is enough to force him to cry, a hilarious response to what had just occurred. Finally, upon trying to saunter out of the space with what little pride Benedick has left, I tripped over the chest completing the golden rule of three ${ }^{8}$. The first occurrence was the retaliation on Beatrice, the second was the humiliation of her presence, and the third was the not-so-elegant exit. "There, he is magnificently absurd, and totally

\footnotetext{
7 "Why he is the prince's jester: a very dull fool; his only gift is in devising impossible slanders: none but degenerates delight in him" (Our retooled script).

8 Three comedic occurrences that allow for the best audience reaction.
} 
unaware of himself (Rossiter 50)". I allowed the audience to ride that wave of energy, the ups and downs of pride and embarrassment, to humorous effect.

Lisa Harrow: Its energy, isn't it? It requires a huge amount of energy to use this language well. So much modern writing is thrown away and deflated. But a speech like that requires a fantastic drive and that's something we need to hold onto and remember (Barton 67).

This energy began at the start of the show when we, Professor Tompkins, Jocelyn, and myself, devised the opening scene with a failed homecoming, the Messenger's spanking, and a practical joke. Professor Tompkins and I wanted Benedick's first appearance on stage to illustrate his showmanship, take-charge attitude, and fondness for playing games. This scene would set up the theme of playing love games that would influence the rest of the piece.

\section{KEEPING THE AUDIENCE IN THE PALMS OF OUR HANDS}

\footnotetext{
"Our approach to Shakespeare naturally must be the approach of our day. The restoration of Shakespeare in the manners and customs of his time is formally impossible and in essence unnecessary. The whole value of the scenic embodiment of a classical work in our day lies namely in the ability to present a work in the refraction of the prism of the contemporary world view (Makaryk 153-163)".
}

Many audiences find the language of Much Ado About Nothing difficult to comprehend which is understandable due to its dense language. This is compounded when an audience is unaware of the usage of Elizabethan text, blank verse, and Shakespeare's writing. Unfortunately for the University of Louisville Theatre Arts Department, its audience is mainly comprised of college students who are required to see performances for classes they are taking. The 
majority of these students are taking TA-207 Enjoyment of Theatre, an introductory theatre history course; it provides them with a Humanities elective so many are unconcerned with the material as long as they pass the course. Most of them leave during intermission or when they think they have gained enough knowledge to pass the exam on the play. This is especially disconcerting for me because I am unable to keep them in the palm of my hand and manipulate their emotions, something I must do to make my theatrical work fulfilling. In order to combat this epidemic, Professor Tompkins, Jocelyn, and myself decided to modernize the script to make it more palatable for an audience of disinterested college students. My goal was to create a piece of theatre that would stimulate an otherwise uninterested audience, ultimately forging a liking for Shakespeare and theatre in general. Sustainability is difficult to achieve when performers do not reach their audience, and this can be catastrophic for a business such as the theatre. I wanted the students to not only understand Much Ado About Nothing, but enjoy it as well; enjoy it enough to pique their interest to see more livetheatre. It is a dying art form and it is my mission to resuscitate it.

Our work began in the summer of 2012; we spent over sixty hours reading the script line by line, word by word, meticulously cutting, rearranging, and rejuvenating Shakespeare's text in the hopes our audience would better understand the themes, motifs, and language. Together, separate, and even via Skype, we created a story that was still true to the original but updated for modern ears, especially the ears of those students taking TA 207. We determined the meaning and intention of each word and when it seemed too 
archaic, tried to update it in such a way that the audience would understand it.

The following is an example:

Original Text:

Will your grace command me to any service to the world's end? I will go on the slightest errand now to the Antipodes that you can devise to send me on. I will fetch you a tooth-picker now from the furthest inch of Asia, bring you the length of Prester John's foot, fetch you a hair off the Great Cham's beard, do you any embassage to the pigmies, rather than hold three words conference with this harpy. (II. i. 229)

Who is Prester John? A legend popular in Europe from the $12^{\text {th }}-17^{\text {th }}$ Centuries (Nowell 435-445). Who is the Great Cham? An archaic spelling of Khan, the title of the Mongol Emperors (Ang 187-188). Would our audience know this? Would the wordplay be understood? No. Therefore we decided to replace references with pop-culture, household celebrities, and names that might appear in gossip magazines for they were a visual reference ${ }^{9}$ to the play's themes of rumor and speculation.

With our revisions:

Will your grace command me to any service to the world's end? I will go now on the slightest errand to the ends of the earth that you can devise to send me on. I will fetch you a toothpick from the furthest inch of Asia, bring you the length of David Beckham's foot, fetch you a hair off ZZ Top's beard, do you an embassage to the pygmy Chuy Bravo, rather than hold three words conference with this harpy.

\footnotetext{
${ }^{9}$ The play's set had pictures of celebrities pasted around the lip of the stage and the false proscenium. The cast also used masks of various celebrities during the masquerade ball.
} 
Who are David Beckham and ZZ Top? You would be hard pressed to find a college student who does not know. Chuy Bravo is a little-person featured on comedian Chelsea Handler's Chelsea Lately; the reference there being his diminutive stature. Other edits included changing words like "cuckold", an archaic word for a man whose wife has cheated on him; "poniard" was changed to "dagger"; "fancy" to "love"; and "mettle" to "substance". All of our modifications were meant to increase the viability of the text for a modern (and usually reluctant) audience while still keeping the quick wit, wordplay, and spine of Shakespeare's text. Sadly, our changes were met with resistance.

Dr. Frye is considered by many of the faculty to be the Shakespeare expert and as department chair, she had the final say on our revisions. She is a purist and prefers Shakespeare to be performed classically and in the style in which it was originally produced. I however have a different perspective: Shakespeare wrote for his audience, the Elizabethan community which included citizens of many socio-economic statuses. Amid the typical Elizabethan language he included in-jokes, slang, and innuendos that only those audience members in the pit, the poor commoners, would understand; this was a way to voice his opinions on matters that the upper-class may not share. Shakespeare actively wrote for a select audience, a tradition we were trying to continue. Dr. Frye did not think that we were doing Shakespeare justice by changing his script and after many attempts to persuade her otherwise she made the final decision that we must use the script as it was written, only allowing for cuts and substitutions of those words which were so archaic that no one would understand 
them. It was a rather devastating blow to the three of us, Professor Tompkins, Jocelyn, and myself because we put so much time and effort into creating a piece of theater that would be enjoyed by the audience; in my opinion, many of the classic plays produced here turn people away from theatre, and we were simply trying to get them excited about it. So we began to refocus our ideas about how to make this play fun for the audience by introducing characterizations, themes, jokes, innuendo, and accents/dialects.

\section{REHEARSAL PROCESS}

The rehearsal process began like many rehearsal processes in that the cast read the script aloud and made the necessary cuts and substitutions as we read along. During our early rehearsals Tompkins reinforced his belief that Shakespeare's plays were not driven by plot but it was in fact the characters that carried the story into the hearts and minds of its audiences. This is something he stated many times during our sessions retooling the script and encouraged us to play around with different characterizations and dialects, which is what led me to choose to portray Benedick as from Eastern Kentucky. The script describes Leonato and Antonio as "two old men without teeth" $(\mathrm{V}, \mathrm{i}, 115)$ so we encouraged the actors to play them as such. Don Pedro and Don John were to use Spanish accents because they were from Aragon, Spain, and Margaret would use a southern American dialect to portray a character with lower status and lower IQ. Dogberry would attempt a standard British dialect which enhanced the humor of his malapropisms. Beatrice and Benedict would be in their forties and rather vain about their appearance so that it can be used against them by one another in the 
play. For example Benedick, being a machismo and lover of women would stuff his pants with a sock so that his penis would appear larger than it really was. Beatrice, on the other hand, would stuff her bra to make her breasts appear larger. These details would lead us to create a bit on stage where Beatrice grabs Benedick's crotch to make fun of him, and Benedick tweaks Beatrice's nipples in retaliation. This all happens in front of the whole town of Messina and within the first ten minutes of the show; it created the tension that would last for the remainder. The audience immediately saw the "merry war" between Beatrice and Benedick at the top of the show. In addition to contemporizing the script, the use of mobile phones as texting devices and cameras continued to develop the theme of gossip and rumor as plot devices; conversations, dalliance, and promiscuity were easily shared with the people of Messina often within minutes of occurrence.

Leaving table-reads behind, the rehearsal process became quite different from those I had become accustomed to during my tenure at the University. Previously, in Measure for Measure and Richard III, a majority of the rehearsal time was spent for "dropping in". This involves sitting across from your scene partner or partners in very close proximity while someone else would read, or feed to you, your lines at which point you would repeat them. The feeder would ask you a variety of questions about your lines including intentions, goals, obstacles, philosophical statements, and the meaning of the lines as you repeated them. In the following example, using Benedick's text from Act I, scene 
$\mathrm{i}$, lines 86-88, the text is underlined, the questions the feeder asks are in italics, and the words that the students repeat after the teacher are in bold.

"Then courtesy \{ Are you courteous? Then courtesy. Is Beatrice courteous to you? Then courtesy. How does Benedick define courtesy?" Then courtesy. $\}$ is a turncoat. $\{$ What is a turncoat? Is a turncoat. Does turncoat mean traitor? Is a turncoat. A traitor to whom? You? Is a turncoat. Does love make you a traitor to your sex? Is a turncoat.\} But it is certain I am loved of all ladies \{Are you certain? But it is certain I am loved of all ladies. Is Jake loved of all ladies? But it is certain I am loved of all ladies. Did an old flame hurt you in the past? But it is certain I am loved of all ladies. Was it Beatrice? But it is certain I am loved of all ladies.\} ..."

While being fed, you were supposed to permit your mind to wander and answer these questions in your head, allowing those answers to inform the way you spoke your lines. This method was supposed to help you delve deeper into the character and formulate reasoning behind how you said your lines to help clarify your character. Eventually, fewer questions are asked and the exercise moves to its feet; it allows the actors to block the scene based on intention and without the need to hold their scripts. During my first go at this, I found it to be a very helpful and interesting way to begin the process of acting in a Shakespearean play. It was also extremely accommodating in terms of memorization because it allowed you to say your lines without fully knowing them, and act on the line in the moment as opposed to constructing preconceived notions about it. However, the act of dropping in became very tedious for me and usually took up so much time that when I was not dropping in I was having my time wasted during rehearsal. The decision to not use "dropping in" for Much Ado was refreshing and allowed me to jump simply into the acting. 
Professor Tompkins focuses on inflections, meaning the rise and fall of the pitch of your voice when you speak. For example, questions generally have a rising-end inflection; the pitch of your voice rises as it reaches the end of the line. Statements generally have a falling-end inflection, meaning the pitch of your voice falls as it reaches the end of the line. These rules are not set in stone and in many ways changing them can dramatically change the way the line is spoken and received. Often a statement with a rising-end inflection keeps the energy going through the end of the line and offers your acting partner a chance to top it. Tompkins would ask us to repeat lines many times with different inflections until we discovered what worked best for the scene.

The process of memorization is different for all actors. I prefer to learn my lines for an entire show as if it was one long monologue. I break up the text into workable chunks, usually based on how the play is divided into acts and scenes. I start with the first line of a section of text and commit it to memory, then learn the second line. Once I have memorized the second, I repeat the first and second together, followed by learning the third and repeating the first, second, and third together. This pattern continues until I can recite the text in the entire section. Once I have an entire section memorized, I move to another and learn it, followed by repeating the first and second sections. When I have completely memorized an entire play, I then begin to recite my lines while completing physical tasks, e.g. washing the dishes, folding clothes, cleaning my apartment, etc. This allows me to say my lines while accomplishing any task, granting me freedom during rehearsals and productions to explore with movement. During 
Much Ado, this was particularly useful because many of our early rehearsals involved improvised movement sequences between Beatrice and Benedick's scenes. It never made it to the final version of the show, but at one time in Act $V$ when I profess my love of Beatrice to the whole town, Jocelyn and I were rolling around on the stage in lascivious and humorous sexual positions.

\section{MY PROCESS DURING THE SHOW}

Some actors need a lengthy process of getting into character. Others can simply turn it on and off, like a light switch. I am one of the latter. I do not need to stay in character all the time or rehearse my lines by myself in order to perform. Many actors run their lines either aloud or in their head before a show but this is something I generally tend not to do. I think that my lines, or rather my character's lines, are to appear to be coming out of his mouth for the very first time and over-rehearsing them, especially before a performance can hinder an actor's spontaneity. Occasionally, backstage before an entrance I might quickly speed through a monologue, but never dialogue between more than one character and myself. It is my own personal preference, but during those moments when I am not on stage with time to myself, I generally do not reflect on the performance. I feel this allows me to live in the moment.

Physical and vocal preparedness are certainly important when doing any theatrical performance, but my training as a actor-combatant allowed me to turn this on and off as well. I learned very quickly how to access muscle memory and proper vocal techniques which would allow for both short bursts and sustained 
physical and vocal activity. Warm-ups behoove any actor, but like fingerprints, no two actors are the same and not all actors need the same amount of time warming up. I would do a small vocal and physical warm-up at home before getting to the theater, despite full-cast warm-ups before the show being available. With such a large cast, I find group warm-ups to be not as valuable as they could be. I also had a rather lengthy makeup application. It consisted of using stage makeup to age myself to appear in my forties, applying gray coloring to my hair, and gluing on two facial hair appliances, a moustache and a goatee. I used my time in the dressing room perfecting my appearance as opposed to spending that time before the show warming up. The dressing room was full, crowded, and noisy, which is why I preferred to listen to music with headphones in order not to be distracted while applying makeup. I would also use this time to prepare mentally for my performance if I felt I needed it.

Perhaps the most important acting technique that pervades my process is active listening; the act of allowing the same energy that permeates an actor's body when he or she is speaking to continue to be exuded when he or she is listening. Not only does this make the actor actually listen to the others' lines but also creates a dynamic performance from the audience's perspective. As Benedick (and all characters I play), when I was not engaged in dialogue I was constantly listening to whomever was speaking. One can often spot a novice actor when they are gauging audience reaction or fiddling with props and not paying attention to what is happening onstage. Active listening is also extremely important to shuttle the focus of the audience to its proper place. If I am engaged 
with another cast member's speech, an audience member looking at me will see that I am listening, and then turn his or her focus to the speaker. Arranging focus when multiple bodies are on display has been a priority of artists of all disciplines, as can be seen in the statue Laocoön and His Sons (Figure 1), Rubens' The Union of Earth and Water (Figure 2), and countless other works of art ranging from classics to present day. Eye contact, gestures, and active listening all force the audience to focus on what the artist chooses, and this tenet is vital to the success of live theatre.

\section{RECEPTION}

The University of Louisville's production of Much Ado About Nothing, despite not being reviewed by any reviewer or theatre blog, was well received by most. The audience often had many great things to say about particular performances and the show as a whole. One specific comment I received was, "You were the best Benedick I have ever seen, and I have seen a lot of productions of this." I had already determined my performance was a success from the audience reactions during the show, but this compliment cemented my opinion. The reviews from the faculty were mixed:

In Much Ado as Benedick I thought he was often funny and had strong presence and comic timing, as Jake always does. He's skilled at playing big personalities and inventing/playing funny "bits" (like eavesdropping behind the tree, for example) so I thought he carried the role off well. He also has a wonderful ability to "think on the line," as Shakespeare coaches say again and again: moments of discovery were clear in his soliloquies. I wondered about the dialect and how it made the transition to the more serious, human moments Benedick has with Beatrice. That is, it almost seemed like the bold character and mask of bravado Benedick carries around could have fallen a little more every now and then ... Jake is fully 
capable of allowing for tenderness and depth ... but it felt like the dialect got in the way of that. If he were continuing, would LOVE to see Jake do a really complex serious role, straight ahead realism, exploring connection and depth of relationship with other actors. - Dr. Amy Steiger

Dr. Steiger makes clear I handled the language adeptly. I agree that I would like to see myself in a more realistic role, but it was never offered the chance on the university's mainstage.

Liked performance very much. Didn't care for dialect. Was it E. Kentucky or generic Southern? In spite of this, thought he played through well. We saw you having fun on stage and in the part without being over the top.

- Dr. Rinda Frye

The longstanding criticism that I overdramatize was corrected and Dr. Frye validated my work.

I love listening to him speaking Shakespeare. He's very skilled at this. I liked how the Southern dialect worked with iambic pentameter, but I found it confusing in this instance. I didn't understand who Benedick was in the story. Was he upper class? Lower class? He seemed to be having fun, but his flourishes sometimes make his characters come across as insincere.

- Nefertiti Burton

Wanted to see the character of Benedick rather than Jake grandstanding. Too much external and not enough internal. Seemed to be making fun of the character. - Dr. Lundeana Thomas

Connects with audience amidst byplay of the opening. As usual for him, high level of commitment to part and the world of the play, his immersion in them is evident. He again has full presence always. He owns the stage. (And I liked the line reading of one ver. ... one virtuous.") Another strong scene for me was Benedick's struggle with the poem in Act II. - Dr. Russell Vandenbroucke (Faculty Reviews).

I was pleased with most of the faculty reviews. I thought they were an acknowledgment of what I was trying to prove, my goals for Benedick. Dr. Thomas's review was unique as it offered only negative feedback, but having been commercially reviewed before, I understand the value of choosing not to let 
feedback such as that affect me. I received several criticisms about my choice of dialect, but I stand by my decision to use it. Professor Tompkins had asked me to experiment with several different dialects and after speaking as an Eastern Kentuckian, he thought it best displayed the masculinity, virility, and humor that audience's look for in a Benedick. I agree. Should I reprise this role, I would work more diligently to accurately convey Eastern Kentuckian and not generically Southern. In addition, opposed to relying only on the dialect, I will look for more proficient ways of using my body to convey status. Had I performed Benedick in the Spring of 2013, a semester in which I pursued such acting and movement techniques, I believe I could have clarified Benedick's character. 


\section{CHAPTER FIVE: CONCLUSION}

After self-reflection and evaluation, I conclude that in order to provide an audience of students with the ability to enjoy, understand, and grow from Shakespearean texts, a modernization of the text is essential. I stand by our original, retooled script, but I agree with Dr. Frye that not everything should be changed. Yes, the audience needs to be able to understand the language, but that does not mean they should not want to research some archaic words at home. It is my job to ignite their passions for Shakespeare, not dumb it down for them. If I cannot encourage them to do so, I have not succeeded. In the case of Much Ado About Nothing, I feel I was victorious.

Because of this, I no longer need the validation and approval of my classmates and teachers at the University of Louisville. I believe I have proven myself to be a competent actor and theatre professional. I was able to keep the audience in palm of my hand and I now have the tools to continue to do so for any performance. Although it was not my choice to play Benedick as my thesis role, I believe my presentation contributed to the success the show achieved as a Shakespearean play performed for an audience of students who normally walk out of the theatre. Professor Tompkins, the Acting teacher I most wanted to impress, confirmed this with a smile and a nod after I finished delivering a monologue during the show. I can now say that my talent is within the realm of his expectations, a terrific feat. 
Theatre is a competitive art form and my goal as an actor is to be the best at what I do. I have a propensity for finding a challenge for myself, conquering it, and moving on to the next challenge. Riding that wave of success I feel does not sustain me, however. I have found myself in the top of my class at the University of Kentucky, been considered to be a fantastic actor in the professional companies I have worked for, and have been told that I am the strongest male actor in the graduate program here at the University of Louisville, yet I am not content to just be the best, to just be on top. I think I secretly enjoy the work it takes to get to the top although I do not like to admit it to myself. My goals for becoming a candidate for a Master's Degree of Fine Arts were to restore my passion for theatre, learn to trust my instincts, and teach college-level courses. My performance as Benedick has helped me complete these. Making Shakespeare palatable for our audiences restored my passion, despite not being able to use our retooled script. I have learned that my instincts were right all along and I can use my own theatrical compass to distinguish good from bad, and use it to benefit my acting, directing, and teaching.

It seems my worries about trying to impress everyone were much ado about nothing. 


\section{Laocoön and His Sons}

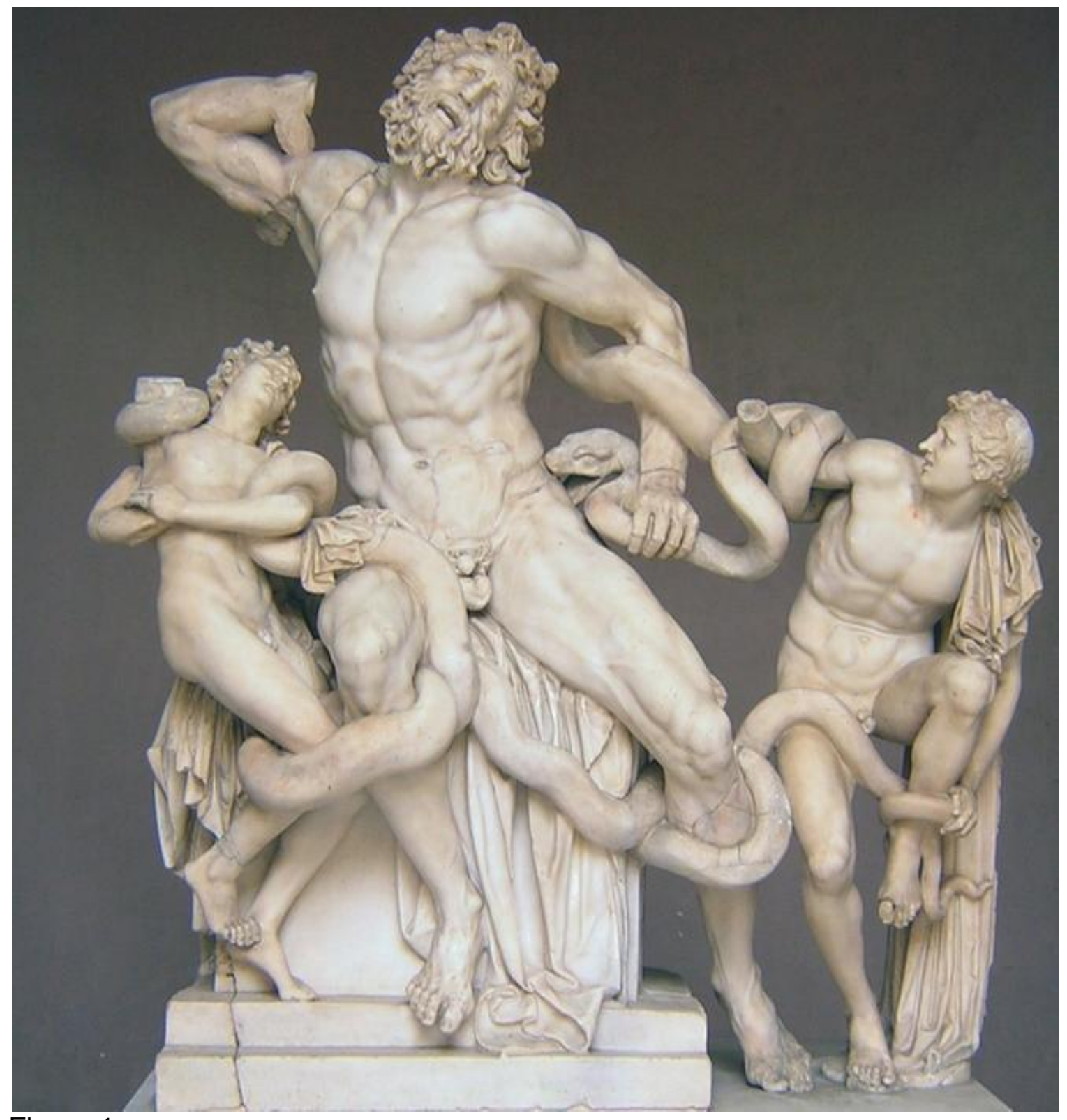

Figure 1. 
The Union of Earth and Water, Peter Paul Reubens

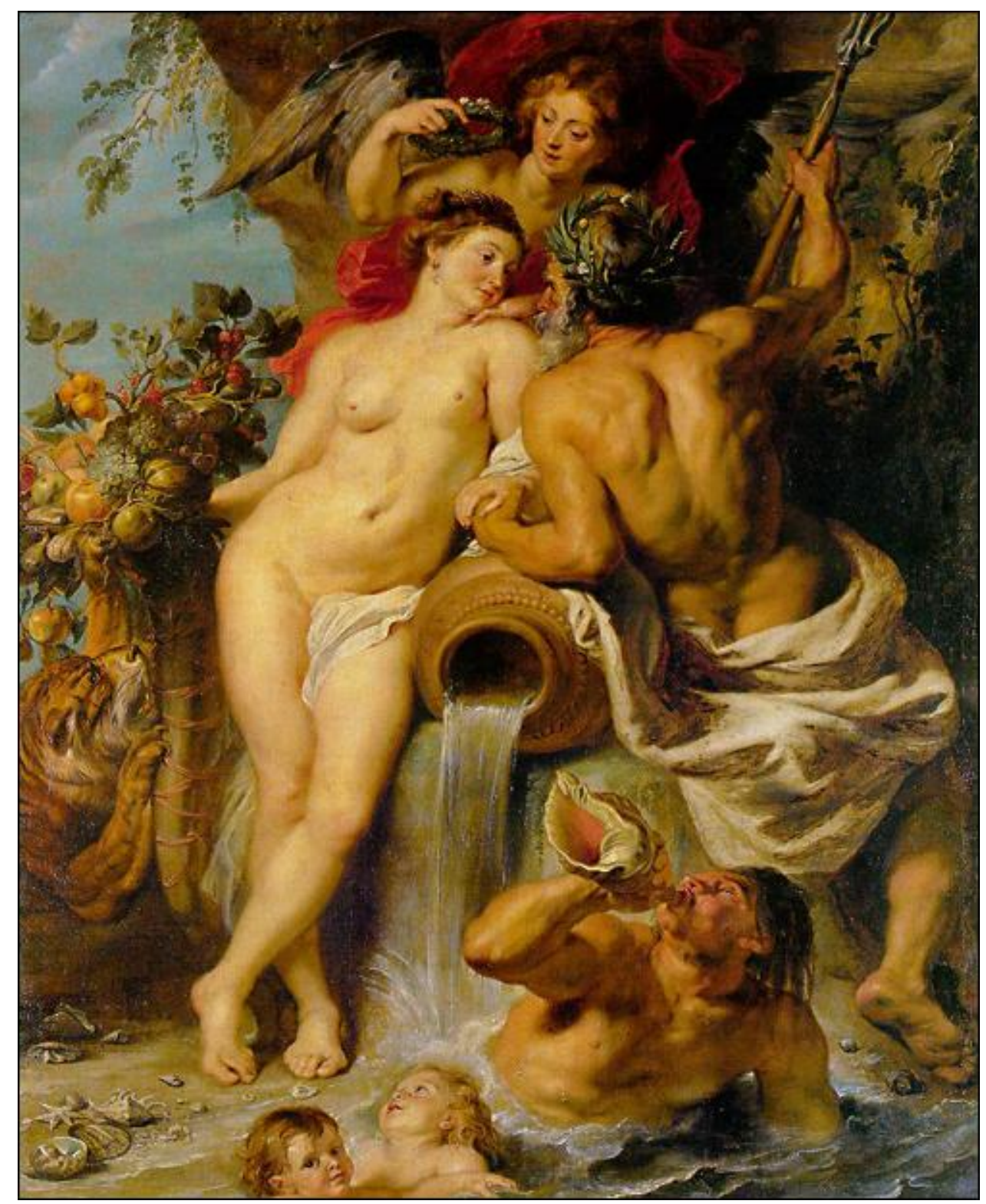

Figure 2. 


\section{REFERENCES}

Agesander, Athenodoros and Polydorus. Laocoön and His Sons. 25 BC. Sculpture. Vatican Museums, Vatican City. Page Pulp. Web. 8 Feb. 2013.

Ang, Gertrude. "Shakespeare's Pygmy Lore." Philippine Quarterly of Culture and Society 5.3 (1977): 187-88. Print.

Barton, John. Playing Shakespeare. London: Methuen in Association with Channel Four Television, 1984. Print.

Cohen, Robert. Acting One. [Palo Alto, Calif.]: Mayfield Pub., 1984. Print.

Faculty Reviews. University of Louisville. 2012.

"misprision." Merriam-Webster.com. Merriam-Webster, 2011. Web. 25 March 2013.

Makaryk, Irena R. "Shakespeare Right and Wrong." Theatre Journal 50.2 (1998): 153-63. Print.

Nowell, Charles E. "The Historical Prester John." Speculum 28.3 (1953): 435-45. Print.

Rossiter, A. P. "Much Ado About Nothing." Shakespeare: The Comedies; a Collection of Critical Essays. Englewood Cliffs, NJ: Prentice-Hall, 1965. 47-57. Print.

Rubens, Peter Paul. The Union of Earth and Water. 1618. Painting. The Hermitage, St. Petersburg. Museum Syndicate. Web. 8 Feb. 2013.

Shakespeare, William, Stephen Greenblatt, Walter Cohen, Jean E. Howard, Katharine Eisaman Maus, and Andrew Gurr. "Much Ado About Nothing." The Norton Shakespeare. New York: W.W. Norton, 1997. 1381-444. Print.

Stanislavski, Constantin. 1936. An Actor Prepares. London: Methuen, 1988. Print. 


\title{
CURRICULUM VITAE
}

\section{Jake Beamer}

\author{
4800 Hunters Point Circle \\ Louisville, KY 40216 \\ jakebeamer@ymail.com \\ 502.494.2637
}

\section{Education}

- High school diploma from Butler Traditional High School, May 2003

- B.A. in theatre, University of Kentucky, Summa Cum Laude, May 2007.

- Recognized as an Actor-Combatant by the Society of American Fight Directors with proficient skills in six weapons, July 2004 and July 2007.

- M.F.A. in performance from the University of Louisville, May 2013.

\section{Employment}

- Six Flags Kentucky Kingdom, Summer 2002, 2003

- Appleseed Heritage Center Inc., actor, Summer, 2004, 2005

- Lexington Shakespeare Festival, actor, Summer 2006

- First Frontier Inc., actor, Summer 2007

- California Theatre Center, actor, 2007-09

- The Ketch Seafood Grill, Lexington, KY, 2006-07, 2009-10

- University of Louisville, President's Office, July 2011 - present

- The Bard's Town Theatre, actor, December 2011, 2012, 2013

\section{Awards}

- Gold Star for Proficient Skills in broadsword, sword \& shield, Society of American Fight Directors, 2007

- Region 4 Finalist, Irene Ryan Acting Scholarship, Kennedy Center American College Theatre Festival, 2012

- Graduate Teaching Assistantship, University of Louisville, 2011-2013 